Abstracta Iranica Abstracta Iranica

Revue bibliographique pour le domaine irano-aryen

Volume 24 | 2003

Comptes rendus des publications de 2001

\title{
Historiens d'Alexandre. Textes traduits et annotés par Janick Auberger, Paris, Les Belles Lettres, 2001, 518 p., index.
}

Rémy Boucharlat

\section{(2) OpenEdition Journals}

Édition électronique

URL : http://journals.openedition.org/abstractairanica/34348

DOI : 10.4000/abstractairanica.34348

ISSN : 1961-960X

Éditeur :

CNRS (UMR 7528 Mondes iraniens et indiens), Éditions de l'IFRI

\section{Édition imprimée}

Date de publication : 15 mai 2003

ISSN : 0240-8910

Référence électronique

Rémy Boucharlat, « Historiens d'Alexandre. Textes traduits et annotés par Janick Auberger, Paris,

Les Belles Lettres, 2001, 518 p., index. », Abstracta Iranica [En ligne], Volume 24 | 2003, document 85, mis en ligne le 05 janvier 2010, consulté le 25 septembre 2020. URL : http://journals.openedition.org/ abstractairanica/34348; DOI : https://doi.org/10.4000/abstractairanica.34348

Ce document a été généré automatiquement le 25 septembre 2020.

Tous droits réservés 


\title{
Historiens d'Alexandre. Textes
} traduits et annotés par Janick Auberger, Paris, Les Belles Lettres, 2001, 518 p., index.

\author{
Rémy Boucharlat
}

1 Depuis l'édition de F. Jacoby, Die Fragmente der griechischer Historiker (Bd. II B: Alexandergeschichte) en 1927, il manquait une édition récente des témoignages des compagnons d'Alexandre, écrits pendant la vie de celui-ci ou peu après. Les ouvrages eux-mêmes de Charès de Mytilène, Néarque, Onésicrite, Ptolémée, Aristobule pour ne citer que les plus connus, ne sont pas parvenus jusqu'à nous. Il n'en reste que les fragments qu'utilisent des historiens postérieurs, grecs et romains, qui souvent et heureusement citent leurs sources.

2 Ces extraits, ici bilingues grec et français, sont donc organisés selon ces auteurs originaux dans les passages, souvent très courts mais parfois très développés, de Diodore, Strabon, Quinte-Curce, Arrien, Plutarque, etc.

3 L'A., qui a déjà donné un excellent Ctesias (1991, Les Belles Lettres) a élaboré un outil de travail très précieux, avec des traductions révisées en regard du texte grec, complétées par des notes; il est facile à utiliser, en particulier en se servant des index (noms de personnages et toponymes). 
INDEX

Thèmes : 3.2.3. Séleucides, Parthes et Sassanides

\section{AUTEURS}

RÉMY BOUCHARLAT

CNRS - Lyon 